\title{
Modification of Cooperativity and Critical Temperatures on a Hofmann-Like Template Structure by Modular Substituent
}

\author{
Takashi Kosone ${ }^{1, *}$, Takeshi Kawasaki ${ }^{2}$, Itaru Tomori ${ }^{2}$, Jun Okabayashi ${ }^{3}$ and \\ Takafumi Kitazawa $2,4, *$ \\ 1 Department of Creative Technology Engineering Course of Chemical Engineering, Anan College, 265 Aoki, \\ Minobayashi, Anan, Tokushima 774-0017, Japan \\ 2 Department of Chemistry, Faculty of Science, Toho University, 2-2-1 Miyama, Funabashi, Chiba 274-8510, \\ Japan; takeshi.kawasaki@sci.toho-u.ac.jp (T.K.); synapse_yf@yahoo.co.jp (I.T.) \\ 3 Research Center for Spectrochemistry, University of Tokyo, Bunkyo-ku, Tokyo 113-0033, Japan; \\ jun@chem.s.u-tokyo.ac.jp \\ 4 Research Centre for Materials with Integrated Properties, Toho University, 2-2-1 Miyama, Funabashi, \\ Chiba 274-8510, Japan \\ * $\quad$ Correspondence: kosone@anan-nct.ac.jp (T.K.); kitazawa@chem.sci.toho-u.ac.jp (T.K.); \\ Tel.: +81-474-72-5077 (T.K.); +81-884-23-7195 (T.K.)
}

Received: 12 July 2017; Accepted: 7 August 2017; Published: 16 August 2017

\begin{abstract}
In a series of Hofmann-like spin crossover complexes, two new compounds, $\left\{\mathrm{Fe}(3-\mathrm{F}-4-\mathrm{Methyl}-\mathrm{py})_{2}\left[\mathrm{Au}(\mathrm{CN})_{2}\right]_{2}\right\}$ (1) and $\left\{\mathrm{Fe}(3-\mathrm{Methyl}-\mathrm{py})_{2}\left[\mathrm{Au}(\mathrm{CN})_{2}\right]_{2}\right\}$ (2) (py = pyridine) are described. The series maintains a uniform 2-dimentional (2-D) layer structure of $\left\{\mathrm{Fe}\left[\mathrm{Au}(\mathrm{CN})_{2}\right]_{2}\right\}$. The layers are combined with another layer by strong aurophilic interactions, which results in a bilayer structure. Both coordination compounds $\mathbf{1}$ and $\mathbf{2}$ at $293 \mathrm{~K}$ crystallize in the centrosymmetric space groups $P 2_{1} / c$. The asymmetric unit contains two pyridine derivative ligands, one type of $\mathrm{Fe}^{2+}$, and two types of crystallographically distinct $\left[\mathrm{Au}(\mathrm{CN})_{2}\right]^{-}$units. Compound $\mathbf{1}$ undergoes a complete two-step spin transition. On the other hand, 2 maintains the characteristic of the high-spin state. The present compounds and other closely related bilayer compounds are compared and discussed in terms of the cooperativity and critical temperature. The bilayer structure is able to be further linked by substituent-substituent contact resulting in 3-dimentional (3-D) network cooperativity.
\end{abstract}

Keywords: coordination polymer; cooperative interaction; crystal engineering; spin crossover

\section{Introduction}

An essential part for designing spin crossover (SCO) materials is to control and optimize the crystal structure [1]. Especially, construction of the strong cooperative intermolecular interactions in the whole of a structure leads to steep transition behavior with a wide hysteresis loop, which is important for the practical materials [2]. The cooperativity is now being investigated by a variety of coordination polymers. Coordination polymers are one of the interesting materials for constructing supramolecular networks. However, systematic designing of the networks is hard because of the structural diversity of coordination polymers.

Since we reported the first Hofmann like SCO coordination polymer $\left\{\mathrm{Fe}(\mathrm{py})_{2}\left[\mathrm{Ni}(\mathrm{CN})_{4}\right]\right\}_{n}(\mathrm{py}=$ pyridine) [3], many derived types of $\left\{\mathrm{Fe}^{\mathrm{II}}(\mathrm{L})_{1 \sim 2}\left[\mathrm{M}^{\mathrm{II}}(\mathrm{CN})_{4}\right]\right\}_{n}[4-9]$ and $\left\{\mathrm{Fe}^{\mathrm{II}}(\mathrm{L})_{1 \sim 2}\left[\mathrm{M}^{\mathrm{I}}(\mathrm{CN})_{2}\right]_{2}\right\}_{n}[10-21]$ $\left(\mathrm{M}^{\mathrm{I}}=\mathrm{Cu}, \mathrm{Ag}\right.$, or $\mathrm{Au}, \mathrm{M}^{\mathrm{II}}=\mathrm{Ni}, \mathrm{Pd}$, or $\mathrm{Pt}, \mathrm{L}=$ pyridine derivatives $)$ have been developed. These compounds show a template 2-dimentional (2-D) sheet structure because of their strongly determinate self-assembly process in which they link octahedral metal centers through the $\mathrm{N}$ atoms of the bidentate $\left[\mathrm{Au}(\mathrm{CN})_{2}\right]^{-}$unit. Therefore, this structural system can be modified only at the axial ligands, $\mathrm{L}$, for 
designing the cooperative networks. Here we report and discuss new Hofmann-like 2-D compounds of the general formula $\left\{\mathrm{Fe}(\mathrm{X}-\mathrm{py})_{2}\left[\mathrm{Au}(\mathrm{CN})_{2}\right]_{2}\right\}(\mathrm{X}=3-\mathrm{F}-4-\mathrm{Methyl}(\mathbf{1})$ or 3-Methyl (2) as shown in Scheme 1).<smiles>Cc1cccnc1</smiles>

Scheme 1. Molecular structure of the ligands of 3-Furuoro-4-methyl-py and 3-Methyl-py.

\section{Results}

\subsection{X-ray Structural Analysis}

\subsubsection{Structure of Compound $\mathbf{1}(\mathrm{T}=293 \mathrm{~K})$}

Compound 1 at $293 \mathrm{~K}$ crystallizes in the monoclinic centrosymmetric space group $P 2_{1} / c$. The asymmetric unit of the complex consists of the hetero-metal $\mathrm{Fe}^{\mathrm{II}} \mathrm{Au}^{\mathrm{I}}$ unit (Figure $1 \mathrm{a}$ ). The $\mathrm{Fe}^{\mathrm{II}}$ ion is octahedrally coordinated by six $\mathrm{N}$ atoms. The Fe-N $\mathrm{N}_{\text {py }}$ bond lengths $(\mathrm{Fe}(1)-\mathrm{N}(1)=2.219(6) \AA, \mathrm{Fe}(1)-\mathrm{N}(2)$ $=2.220(6) \AA)$ are longer than the $\mathrm{Fe}-\mathrm{N}_{\mathrm{CN}}$ bond lengths $(\mathrm{Fe}(1)-\mathrm{N}(3)=2.142(7) \AA, \mathrm{Fe}(1)-\mathrm{N}(4)=2.153(6) \AA$, $\mathrm{Fe}(1)-\mathrm{N}(5)=2.160(7) \AA, \mathrm{Fe}(1)-\mathrm{N}(6)=2.148(6) \AA)$. The average lengths of $\mathrm{Fe}-\mathrm{N}_{\mathrm{py}}=2.220 \AA$ and $\mathrm{Fe}-\mathrm{N}_{\mathrm{CN}}$ $=2.151 \AA$ (total average length of $\mathrm{Fe}-\mathrm{N}=2.185 \AA$ are estimated). All $\mathrm{Au}^{\mathrm{I}}$ atoms have linear coordination geometries with the $\mathrm{CN}$ substituents binding to the $\mathrm{Fe}^{\mathrm{II}}$ ions. While the $\mathrm{F}(1)$ in the 3-F-4-Me-py ligand is disordered, the $\mathrm{F}(2) \mathrm{F}(3)$ in the other 3-F-4-Me-py ligand are not disordered. Thus, the two 3-F-4-Me-py ligands in [Fe $\left.{ }^{\mathrm{II}}(3-\mathrm{F}-4-\mathrm{Me}-\mathrm{py})_{2}\right]\left[\mathrm{Au}^{\mathrm{I}}(\mathrm{CN})_{2}\right]$ are not equivalent and coexist in transoid and cisoid conformations for $\mathrm{Fe}(1)$. The bidentate $\left[\mathrm{Au}^{\mathrm{I}}(\mathrm{CN})_{2}\right]$ linear units give rise to an infinite corrugated 2-D mesh-layer formed by the assembly of $-\mathrm{Au}-\mathrm{N}-\mathrm{C}-\mathrm{Fe}-\mathrm{C}-\mathrm{N}-\mathrm{Au}$ - infinite chains (Figure 1b). In addition, the layers interact by pairs to define bilayers which stem from strong aurophilic interactions (Figure 1c). The average Au ‥A Au distance in the bilayers is $3.142 \AA$, less than the sum of the van der Waals radii of $\mathrm{Au}(3.60 \AA)$. The nearest aromatic rings form almost face-to-face superposition (dihedral angles $=8.55^{\circ}$ ). It constructs weak $\pi$-stacking interactions. The closet $C_{p y} \cdots C_{\text {py }}$ distances between py rings $[C(2) \cdots C(8)=3.548(13) \AA]$ are smaller than the sum of the van der Waals radius (ca. $3.70 \AA$ ).

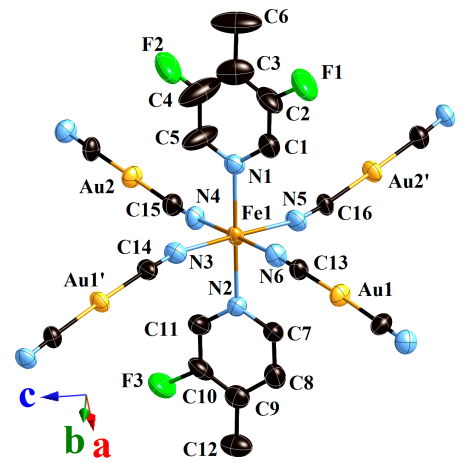

(a)

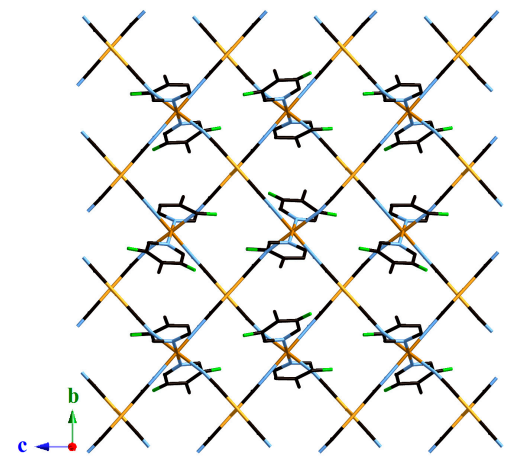

(b)

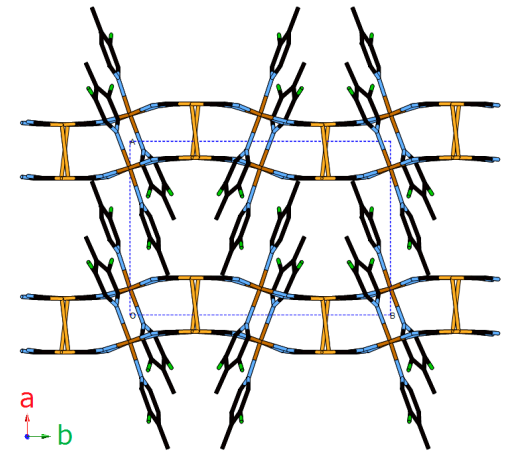

(c)

Figure 1. (a) Coordination structure of compound 1 containing its asymmetric unit at $293 \mathrm{~K}$; (b) View of the 2-D layer structure of $\mathbf{1}$; (c) Stacking of four consecutive layers of $\mathbf{1}$ at $293 \mathrm{~K}$. In these pictures, hydrogen atoms are omitted for clarity.

\subsubsection{Structure of Compound $\mathbf{1}(\mathrm{T}=180 \mathrm{~K})$}

The crystal structure of this state is similar to that for 293 and $90 \mathrm{~K}$. However, as compared to the fully high spin (HS) state, the single crystals lose their qualities due to the narrow temperature 
region of the half transition phase. As a result, the crystal data at $180 \mathrm{~K}$ is not good enough $(R=0.1058$ [I > 2sigma (I)]) for determining the correct structure (see Table S1). So, here we discuss in detail the structure at $293 \mathrm{~K}$ (fully high spin (HS) state) and $90 \mathrm{~K}$ (fully low spin (LS) state).

\subsubsection{Structure of Compound $1(\mathrm{~T}=90 \mathrm{~K})$}

The crystal structure of $\mathbf{1}$ at $90 \mathrm{~K}$ is almost identical to that observed at $293 \mathrm{~K}$. The Fe- $\mathrm{N}_{\text {py }}$ bond lengths $(\mathrm{Fe}(1)-\mathrm{N}(1)=2.013(4) \AA, \mathrm{Fe}(1)-\mathrm{N}(2)=2.002(4) \AA)$ are longer than the $\mathrm{Fe}-\mathrm{N}_{\mathrm{CN}}$ bond lengths $[\mathrm{Fe}(1)-\mathrm{N}(3)=1.942(4) \AA, \mathrm{Fe}(1)-\mathrm{N}(4)=1.944(4) \AA, \mathrm{Fe}(1)-\mathrm{N}(5)=1.934(4) \AA, \mathrm{Fe}(1)-\mathrm{N}(6)=1.936(4) \AA]$. Total average length is estimated as $\mathrm{Fe}-\mathrm{N}=1.962 \AA$. The change of the average length upon spin transition is $0.223 \AA$, which is almost identical with the expected values for the $\mathrm{Fe}^{\mathrm{II}} 100 \%$ LS state. The rings form more parallel superposition than that of the HS state (dihedral angles $=2.57^{\circ}$ ).

\subsubsection{Structure of Compound $2(\mathrm{~T}=293 \mathrm{~K})$}

The crystal structure of $\mathbf{2}$ at $293 \mathrm{~K}$ is almost similar to that of $\mathbf{1}$ at $293 \mathrm{~K}$ which also crystallizes in the monoclinic centrosymmetric space group $P 2_{1} / c$. The 2-D bilayer structure is also almost same shape ( $\mathrm{Au} \cdots \mathrm{Au}$ distance is $3.174 \AA$ ) (Figure 2). However, local differences are observed. The rings array is slightly more unparallel than that of $\mathbf{1}$ (dihedral angles $\left.=11.97^{\circ}\right)$. However, weak $\pi$-stacking interactions are also observed $(C(1) \cdots C(10)=3.542(10) \AA)$. There is a trans orientation of 3-Me substituents with respect to the $\mathrm{N}(1)-\mathrm{Fe}-\mathrm{N}(2)$ axis. The $\mathrm{Fe}-\mathrm{N}_{\text {py }}$ bond lengths $(\mathrm{Fe}(1)-\mathrm{N}(1)=$ 2.247(4) $\AA, \mathrm{Fe}(1)-\mathrm{N}(2)=2.244(4) \AA)$ are longer than the $\mathrm{Fe}-\mathrm{N}_{\mathrm{CN}}$ bond lengths $[\mathrm{Fe}(1)-\mathrm{N}(3)=2.164(4) \AA$, $\mathrm{Fe}(1)-\mathrm{N}(4)=2.162(4) \AA, \mathrm{Fe}(1)-\mathrm{N}(5)=2.159(4) \AA, \mathrm{Fe}(1)-\mathrm{N}(6)=2.158(4) \AA]$. The average lengths of $\mathrm{Fe}-\mathrm{N}_{\mathrm{py}}=2.246 \AA$ and $\mathrm{Fe}-\mathrm{N}_{\mathrm{CN}}=2.162 \AA$ (total average length of $\mathrm{Fe}-\mathrm{N}=2.204 \AA$ are also estimated).

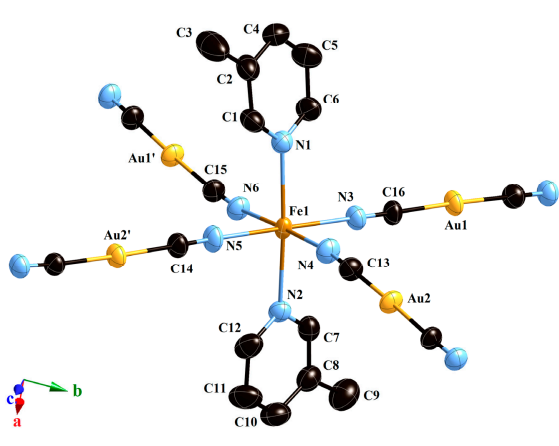

(a)

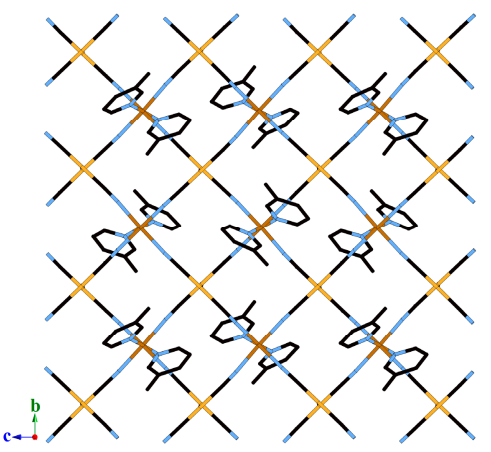

(b)

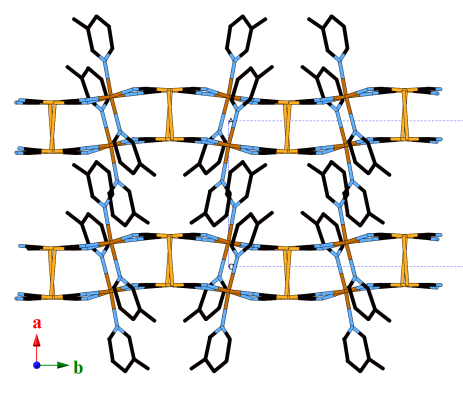

(c)

Figure 2. (a) Coordination structure of compound 2 containing its asymmetric unit at $293 \mathrm{~K}$; (b) View of the 2-D layer structure of 2; (c) Stacking of four consecutive layers of $\mathbf{2}$ at $293 \mathrm{~K}$. In these pictures, hydrogen atoms are omitted for clarity.

\subsection{Magnetic Properties}

\subsubsection{Thermal Dependence Magnetic Behavior of Compound 1}

Figure 3a shows the thermal dependence of $\chi_{M} T$ for 1 with $\chi_{M}$ being the molar magnetic susceptibility and $T$ the temperature. At room temperature, $\chi_{\mathrm{M}} T$ is $3.65 \mathrm{~cm}^{3} \cdot \mathrm{K} \cdot \mathrm{mol}^{-1}$. This value is slightly higher than usual for paramagnetic $\mathrm{Fe}^{\mathrm{II}}$ compounds, possibly due to oxidation of the complex. Upon cooling, $\chi_{M} T$ remains almost constant down to $195 \mathrm{~K}$; below this temperature, $\chi_{M} T$ undergoes a sharp decrease. The complex displays two-step spin transition with a characteristic plateau centered at around 50\% conversion, and the warming mode reveals the occurrence of a hysteresis loop (second step). The SCO for this complex causes a reversible change of color from blue (HS) to purple (LS). The critical temperature $\left(T_{\mathrm{c}}\right)$ in the first step $\left(T_{\mathrm{c}}{ }^{1}\right)$ is $188.5 \mathrm{~K}$ and the cooling $\left(T_{\mathrm{c}}{ }^{2 \text { down }}\right)$ and warming 
$\left(T_{\mathrm{c}}^{2}\right.$ up ) modes in the second step are 164.5 and $171.5 \mathrm{~K}$, respectively, giving an approximately $7.0 \mathrm{~K}$ width hysteresis loop.

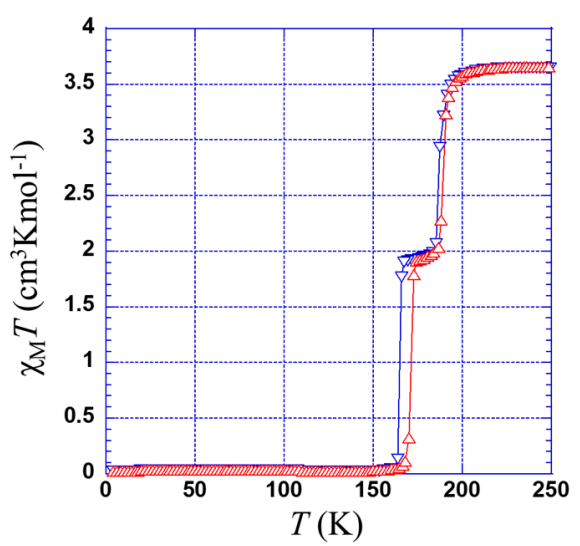

(a)

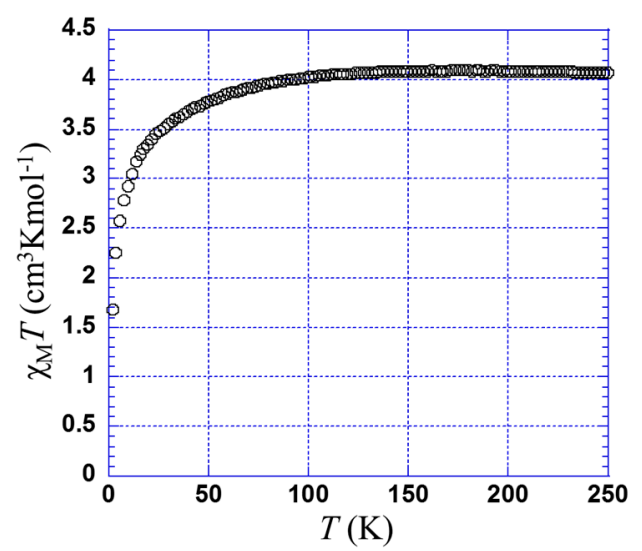

(b)

Figure 3. (a) Thermal dependence of $\chi_{\mathrm{M}} T$ for compound 1. The sample was cooled from 300 to $2 \mathrm{~K}$ (blue) and then warmed from 2 to $300 \mathrm{~K}$ (red). (b) Thermal dependence of $\chi_{\mathrm{M}} T$ for compound 2.

\subsubsection{Thermal Dependence Magnetic Behavior of Compound 2}

$\chi_{\mathrm{M}} T$ versus $T$ plots for 2 are shown in Figure 3b. At room temperature, the magnetic behavior of the complex 2 is characteristic of Fe(II) compounds in the HS state, $\chi_{\mathrm{M}} T=4.05 \mathrm{~cm}^{3} \cdot \mathrm{K} \cdot \mathrm{mol}^{-1}$. The value is slightly higher than that of a pure spin only system, whereas the value is similar to the values of other Hofmann-like SCO Fe ${ }^{\mathrm{II}}$ compounds. The $\chi_{\mathrm{M}} T$ value is nearly constant in the range of $80-300 \mathrm{~K}$. However, it decreases steeply as the temperature is lowered to less than $30 \mathrm{~K}$. The decrease in the value of $\chi_{M} T$ at lower temperatures is due to a typical behavior of zero-field splitting (ZFS) effects of the metallic $\mathrm{Fe}^{\mathrm{II}}$ centers in the residual HS $(\mathrm{S}=2)$ species [22].

\section{Discussion}

The bilayer structures of $\mathbf{1}$ and $\mathbf{2}$ are almost identical with the former reported compounds of $\left\{\mathrm{Fe}^{\mathrm{II}}(\mathrm{L})_{2}\left[\mathrm{Au}^{\mathrm{I}}(\mathrm{CN})_{2}\right]_{2}\right\}$ ( $\mathrm{L}=$ pyridine derivatives). In the previous papers, the synthesis and characterization of the closely related bilayer structures of $\left\{\mathrm{Fe}(\mathrm{X}-\mathrm{py})_{2}\left[\mathrm{Au}(\mathrm{CN})_{2}\right]_{2}\right\}(\mathrm{X}=3-\mathrm{F}(3)[12,13,15]$, 4-Methyl (4) [17], 3-Br (5) [12], and 3-Br-4-Methyl (6) [16]) have been reported. These analogous compounds are also discussed in this paper.

Cell volumes, SCO behavior type, and $T_{\mathrm{c}}$ for $\mathbf{1 - 6}$ are summarized in Table 1 . It is noted that the cell volume clearly shows an expansion with the increase of the substituent bulk. The compounds from smallest to largest are as follows: 3-F-py $\left(1915.7 \AA^{3}\right)<3$-Methyl-py $\left(1976.3 \AA^{3}\right)<3$-Br-py $\left(1990.9 \AA^{3}\right)<$ 4-Methyl-py $\left(2112.5 \AA^{3}\right)<3$-F-4-Methyl-py $\left(2155.2 \AA^{3}\right)<3$-Br-4-Methyl-py $\left(2209.7 \AA^{3}\right)$. In spite of the lattice expansion, these compounds completely maintain a bilayer structure.

In terms of the magnetic properties of $\mathbf{1}$ and $\mathbf{2 ,} \mathbf{1}$ displays a steep two-step spin conversion with a hysteresis loop (second step), while $\mathbf{2}$ is fully HS in the whole range of temperatures. This result suggests that the $T_{\mathrm{c}}$ of $\mathbf{2}$ might be so low that no spin transition is observed in an ambient pressure. There is also no spin conversion observed for $X=3-\mathrm{Br}$. In this series, $T_{\mathrm{c}}$ increases in the following way: 3-Me-py, 3-Br-py (no transition) <<3-Br-4-Me-py (109.1 K) < 3-F-py (first step $147.9 \mathrm{~K}$ ) < 3-F-4-Me-py (first step $188.5 \mathrm{~K}$ ) < 4-Me-py (first step $210 \mathrm{~K}$ ). The order of $T_{\mathrm{c}}$ must result from the difference in the ligand field strength $\Delta_{\mathrm{o}}$. It seems that the 4-Me substituent is the most effective for decreasing $\Delta_{\mathrm{o}}$ (see Scheme S1). This trend of $T_{\mathrm{c}}$ is in the same order for $\left[\mathrm{Fe}(\mathrm{L})_{2} \mathrm{Ag}(\mathrm{CN})_{2}\right](\mathrm{L}=3-\mathrm{F}-\mathrm{py}, 3-\mathrm{Br}-\mathrm{py}$, 3-Me-py, and 4-Me-py) and is as follows: 3-Me-py [18], 3-Br-py (no transition) [11] $<<3-F-p y$ (first step 
$146.3 \mathrm{~K}$ ) [11] < 4-Mepy (first step $189 \mathrm{~K}$ ) [18]. These orders of $T_{\mathrm{C}}$ are opposite to the expected electronic effect according to the Hammet constants [23].

Table 1. Spin crossover (SCO) behavior types, cell volumes, and critical temperatures of $\left\{\mathrm{Fe}^{\mathrm{II}}(\mathrm{X}-\mathrm{py})_{2}\left[\mathrm{Au}^{\mathrm{I}}(\mathrm{CN})_{2}\right]_{2}\right\}$ at $293 \mathrm{~K}$ or room temperature.

\begin{tabular}{ccccc}
\hline Substituents & $\begin{array}{c}\text { Cell Volume } \\
\left(\AA^{3} \mathbf{)}\right.\end{array}$ & SCO Behavior Type & $\begin{array}{c}\text { Critical } \\
\text { Temperature } \boldsymbol{T}_{\mathbf{c}} \\
\text { (K) }\end{array}$ & Ref. \\
\hline 3-Methyl (2) & $1976.30 \AA^{3}$ & None & None & - \\
4-Methyl (HS) (4) & $2112.5 \AA^{3}$ & Steep (3-step) & $210 \mathrm{~K}$ (first step) & {$[17]$} \\
3-Fuluoro (HS) (3) & $1915.7 \AA^{3}$ & Steep (2-step) & $147.9 \mathrm{~K}$ (first step) & {$[12,13,15]$} \\
3-Fuluoro-4-Methyl (HS) (1) & $2155.2 \AA^{3}$ & Steep (2-step) & $188.5 \mathrm{~K}$ (first step) & - \\
3-Bromo (5) & $1990.9 \AA^{3}$ & None & None & {$[12]$} \\
3-Bromo-4-Methyl (HS) (6) & $2204.5 \AA^{3}$ & Steep (1-step, 50\% transition) & $109.1 \mathrm{~K}$ & {$[16]$} \\
\hline
\end{tabular}

In a previous related study, Real and co-workers discussed the effect of substituted pyridines for the analogous series of $\left[\mathrm{Fe}(\mathrm{X}-\mathrm{py})_{2} \mathrm{Ag}(\mathrm{CN})_{2}\right]\left(\mathrm{X}=\right.$ halogen atoms) [11]. The research says that $T_{\mathrm{c}}$ may be dominantly influenced by crystal packing factor and polymeric structure. We interpret the former research as meaning that the Fe-N bond length is strongly influenced by the interlayer spaces. The steric effect from substituent bulk makes the space tight. In fact, 4-position is vertical to the layer. Thus, a 4-Methyl substituent gives rise to higher chemical pressure in the $\mathrm{Fe}-\mathrm{N}$ bond. Consequently, the trend of $T_{\mathrm{c}}$ can be explained by the substituent bulk. Electronic effects righteously coexist and compete with steric effects.

Both $\mathbf{1}$ and $\mathbf{3}$ have significantly similar transition behavior. However, each behavior has a different hysteresis width. In compound 3, intermolecular distance between F $\cdots F$ is significantly shorter as compared to that of $\mathbf{1}$ (Scheme 2). The crystal structure of $\mathbf{3}$ shows the lowest cell volume which makes the interlayer spaces narrow. It results in shorter F $\cdots F$ contact (closest distance of F $\cdots F(H S)=3.104 \AA$ ) between bilayers. Specifically, the half spin transition state (HS-LS) has extremely short F $\cdots$ F contact $(2.955 \AA)$. Therefore, this complex must have higher cooperative networks which stabilize the HS-LS

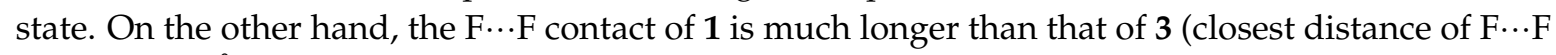
$(\mathrm{HS})=3.717 \AA$ ). This longer distance of $\mathbf{1}$ is due to the 4 -Me substituent which serves as bulk for the expansion along the $a$ axis between the layers. Thus it generates weakened cooperativity. In fact, the thermal trapping of the HS-LS state for $\mathbf{3}$ is observed (see Figure S1), while this process cannot be seen for $\mathbf{1}$ at the same cooling/warming rate. This result is also strongly supported by the difference in the cooperativity of $\mathbf{1}$ and $\mathbf{3}$. SCO behavior types, hysteresis width, closest approach F...F distance, and presence or absence of thermal trapping for $\mathbf{1}$ and $\mathbf{3}$ are summarized in Table 2.

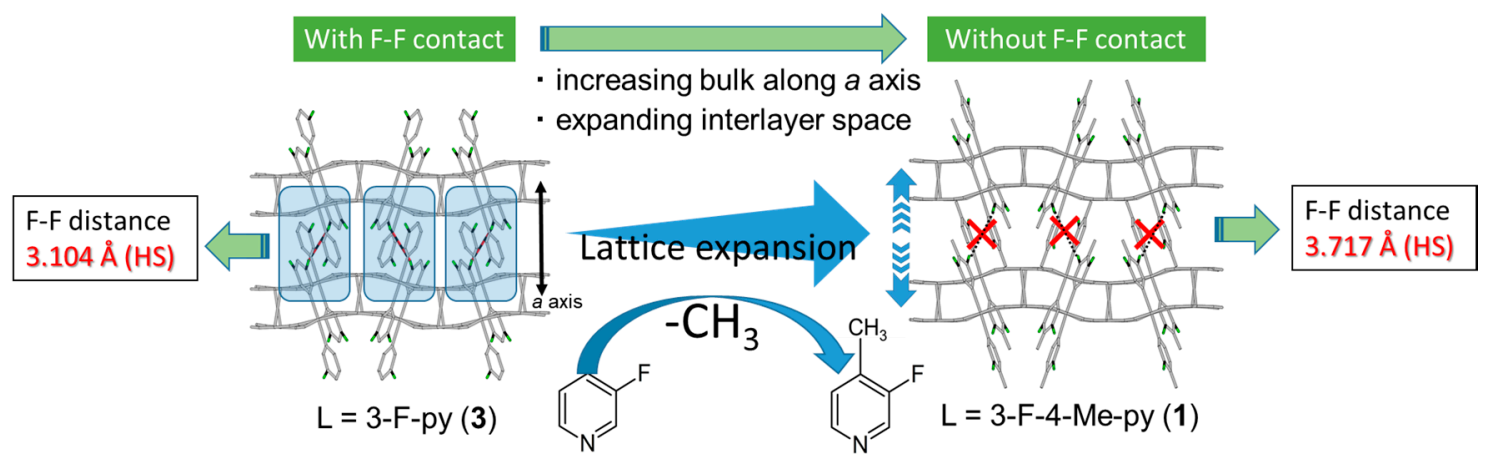

Scheme 2. Representation of the lattice expansion with the addition of the 4-position substituent. Blue highlighted box shows the F...F interactions (black and red dotted line). 
Table 2. Comparative hysteresis width, closest approach F...F distances, and presence or absence of thermal trapping for compounds $\mathbf{1}$ and $\mathbf{3}$. SI = supplemental information.

\begin{tabular}{|c|c|c|c|}
\hline $\mathrm{Fe}(\mathrm{X}-\mathrm{py})_{2}\left[\mathrm{Au}(\mathrm{CN})_{2}\right]_{2}$ & Hysteresis Width (K) & 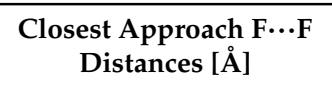 & $\begin{array}{c}\text { Thermal Trapping After } \\
\text { Cooling at } 2 \mathrm{~K} / \mathrm{min}\end{array}$ \\
\hline$X=3-F(3)$ & ca. $40 \mathrm{~K}$ & $\begin{array}{c}\mathrm{F}(1) \cdots \mathrm{F}(1): 3.104 \AA \text { (HS) } \\
\mathrm{F}(1) \cdots \mathrm{F}(1): 2.955 \AA \\
(\mathrm{HS}-\mathrm{LS}) \mathrm{F}(3) \cdots \mathrm{F}(3): 3.264 \\
\AA \text { (LS) }\end{array}$ & Observed (see SI) \\
\hline $\mathrm{X}=3-\mathrm{F}-4-\mathrm{Me}(\mathbf{1})$ & ca. $7 \mathrm{~K}$ & $\begin{array}{l}F(3) \cdots F(3): 3.717 \AA \text { (HS) } \\
F(2) \cdots F(3): 3.305 \AA(L S)\end{array}$ & None \\
\hline
\end{tabular}

\section{Materials and Methods}

\subsection{Materials}

All the chemicals were purchased from commercial sources and used without any further purification.

\subsection{Preparation of Compounds $\mathbf{1}$ and $\mathbf{2}$}

To $10 \mathrm{~mL}$ of water, $\mathrm{FeSO}_{4} \cdot\left(\mathrm{NH}_{4}\right)_{2} \mathrm{SO}_{4} \cdot 6 \mathrm{H}_{2} \mathrm{O}(0.10 \mathrm{mmol}, 39.2 \mathrm{mg})$ and $\mathrm{K}\left[\mathrm{Au}(\mathrm{CN})_{2}\right](0.1 \mathrm{mmol}$, $28.8 \mathrm{mg}$ ) were dissolved. The vapor diffusion method using 3-F-4-Me-py or 3-Me-py as a source of ligand molecules provided colorless single crystals suitable for $\mathrm{X}$-ray diffraction of $\mathbf{1 - 2}$ over a period of two days. Elem. Anal. Calcd. for $\mathrm{C}_{16} \mathrm{H}_{12} \mathrm{~N}_{6} \mathrm{~F}_{2} \mathrm{Au}_{2} \mathrm{Fe}(\mathbf{1})$ : $\mathrm{C}, 25.76 ; \mathrm{H}, 1.56 ; \mathrm{N}, 10.83$. Found: $\mathrm{C}, 25.98$; $\mathrm{H}, 1.58 ; \mathrm{N}, 10.90$. Calcd. for $\mathrm{C}_{16} \mathrm{H}_{14} \mathrm{~N}_{6} \mathrm{Au}_{2} \mathrm{Fe}$ (2): C, 25.97; H, 1.91; N, 11.36. Found: C, 25.78; H, 1.92; $\mathrm{N}, 11.35$.

\subsection{Magnetic Measurements}

Measurements of the temperature dependence of the magnetic susceptibility of the complexes 1 and 2 of the powdered samples in the temperature range of $2-300 \mathrm{~K}$ with a cooling and heating rate of $2 \mathrm{~K} \cdot \mathrm{min}^{-1}$ in a $1 \mathrm{kOe}$ field were measured on a MPMS-XL Quantum Design SQUID magnetometer in the Cryogenic Research Center, the University of Tokyo. The diamagnetism of the samples and sample holders were taken into account.

\subsection{X-ray Crystallography}

Data collection was performed on a BRUKER APEX SMART CCD area-detector diffractometer at 293, $180 \mathrm{~K}$, and $90 \mathrm{~K}$ for $\mathbf{1}$ and $\mathbf{2}$ with monochromated Mo-K $\alpha$ radiation $(\lambda=0.71073 \AA)$ (Bruker, Billerica, MA, USA). A selected single crystal was carefully mounted on a thin glass capillaly and immediately placed under a liquid $\mathrm{N}_{2}$ cooled $\mathrm{N}_{2}$ stream in each case. Crystal structures of the complexes $\mathbf{1}$ and $\mathbf{2}$ were determined using a BRUKER APEX SMART CCD area-detector diffractometer with monochrometed Mo K $\alpha$ radiation $(\lambda=0.71073 \AA)$. The diffraction data were treated using SMART and SAINT, and absorption correction was performed using SADABS [24]. The structures were solved by using direct methods with SHELXTL [25]. All non-hydrogen atoms were refined anisotropically, and the hydrogen atoms were generated geometrically. Pertinent crystallographic parameters and selected metric parameters for $\mathbf{1}$ and $\mathbf{2}$ are displayed in Tables S1 and S2. Crystallographic data have been deposited with Cambridge Crystallographic Data Centre: Deposition numbers CCDC-1559723 for compound $\mathbf{1}$ (293 K), CCDC-1559724 for $\mathbf{1}$ (90 K), and CCDC-1559832 for $\mathbf{2}$ (293 K). These data can be obtained free of charge via http://www.ccdc.cam.ac.uk/conts/retrieving.html.

\section{Conclusions}

In this paper, the 2-D bilayer structures of Hofmann-like coordination polymers $\left\{\mathrm{Fe}^{\mathrm{II}}(\mathrm{X}-\mathrm{py})_{2}\left[\mathrm{Au}^{\mathrm{I}}(\mathrm{CN})_{2}\right]_{2}\right\}$ were synthesized. It is noted that the substituents of pyridine derivatives 
have two steric effects in the whole of the crystal structure. One is the blocking interlayer spaces resulting in modification of the cooperativity. The other is the chemical pressure to the $\mathrm{Fe}^{\mathrm{II}}$ centers resulting in modification of the critical temperature. The two effects are opposite forces to each other, like action-reaction forces with a wall.

In general, the 3-D coordination bonding types, such as $\left[\mathrm{Fe}^{\mathrm{II}}\right.$ (pyrazine) $\left.\left[\mathrm{M}^{\mathrm{II}}(\mathrm{CN})_{4}\right]\right\}(\mathrm{M}=\mathrm{Ni}, \mathrm{Pd}$, and $\mathrm{Pt}$ ) display stable discontinuous spin transitions with strong cooperativity. On the other hand, most of the 2-D coordination types had weaker cooperativity than that of the 3-D type.

However, the present 2-D system shows a strong cooperativity that is as strong as the 3-D type due to the substituent-substituent interaction.

The 2-D coordination structure can be used in designs due to the unique properties, such as gate-opening behavior [26]. Therefore, the 2-D structure would create novel and unique SCO material with strong cooperativity for practical applications.

Supplementary Materials: The following are available online at www.mdpi.com/2304-6740/5/3/55/s1, Scheme S1: Critical temperature $\left(T_{\mathrm{c}}\right)$ changes depending on the substituent of $\left\{\mathrm{Fe}(\mathrm{X}-\mathrm{py})_{2}\left[\mathrm{Au}(\mathrm{CN})_{2}\right]_{2}\right\}(\mathrm{X}=$ 3-F-4-Methyl (1), 3-Methyl (2), 3-F (3), 4-Methyl (4), 3-Br (5) and 3-Br-4-Methyl (6)), Figure S1: Thermal dependence of spin transition curve for compound 3 . The sample was cooled from 300 to $2 \mathrm{~K}$ at a rate of $2 \mathrm{~K} \cdot \mathrm{min}^{-1}$ and then warmed again to $300 \mathrm{~K}$ at a rate of $2 \mathrm{~K} \cdot \mathrm{min}^{-1}$. Table S1: Crystal data and structure refinement for compounds 1 and 2, Table S2: Selected bond lengths for compounds 1 and 2. For CIF, check CIF files.

Acknowledgments: A part of this work was supported by a Ministry of Education, Culture, Sports, Science, and Technology, Japan (MEXT)-Supported program for the Strategic Research Foundation at Private Universities 2012-2016. This work was also supported by JSPS KAKENHI Grant Number 15K05485.

Author Contributions: Takashi Kosone, Itaru Tomori, and Takeshi Kawasaki carried out the synthesis, XRD measurements with the structural analysis, and Jun Okabayashi carried out the magnetic measurements. Takashi Kosone and Takafumi Kitazawa interpreted and discussed the result.

Conflicts of Interest: The authors declare no conflict of interest.

\section{References}

1. Real, J.A.; Andrés, E.; Munoz, M.C.; Julve, M.; Granier, T.; Bousseksou, A.; Varret, F. Spin crossover in a catenane supramolecular system. Science 1995, 268, 265-268. [CrossRef] [PubMed]

2. Gütlich, P.; Garcia, Y.; Goodwin, H.A. Spin crossover phenomena in Fe(II) complexes. Chem. Soc. Rev. 2000, 29, 419-427. [CrossRef]

3. Kitazawa, T.; Gomi, Y.; Takahashi, M.; Takeda, M.; Enomoto, M.; Miyazaki, A.; Enoki, T. Spin-crossover behaviour of the coordination polymer $\mathrm{Fe}^{\mathrm{II}}\left(\mathrm{C}_{5} \mathrm{H}_{5} \mathrm{~N}\right)_{2} \mathrm{Ni}^{\mathrm{II}}(\mathrm{CN})_{4}$. J. Mater. Chem. 1996, 6, 119-121. [CrossRef]

4. Niel, V.; Martinez-Agudo, J.M.; Muñoz, M.C.; Gaspar, A.B.; Real, J.A. Cooperative Spin Crossover Behavior in Cyanide-Bridged Fe(II)-M(II) Bimetallic 3D Hofmann-like Networks (M = Ni, Pd, and Pt). Inorg. Chem. 2001, 40, 3838-3839. [CrossRef] [PubMed]

5. Agusti, G.; Cobo, S.; Gaspar, A.B.; Molnár, G.; Moussa, N.O.; Szilágyi, P.Á.; Pálfi, V.; Vieu, C.; Carmen Muñoz, M.; Real, J.A.; et al. Thermal and light-induced spin crossover phenomena in new 3D Hofmann-like microporous metalorganic frameworks produced as bulk materials and nanopatterned thin films. Chem. Mater. 2008, 20, 6721-6732. [CrossRef]

6. Martínez, V.; Gaspar, A.B.; Muñoz, M.C.; Bukin, G.V.; Levchenko, G.; Real, J.A. Synthesis and Characterisation of a New Series of Bistable Iron(II) Spin-Crossover 2D Metal-Organic Frameworks. Chem. Eur. J. 2009, 15, 10960-10971. [CrossRef] [PubMed]

7. Bartual-Murgui, C.; Ortega-Villar, N.A.; Shepherd, H.J.; Muñoz, M.C.; Salmon, L.; Molnár, G.; Bousseksou, A.; Real, J.A. Enhanced porosity in a new 3D Hofmann-like network exhibiting humidity sensitive cooperative spin transitions at room temperature. J. Mater. Chem. 2011, 21, 7217. [CrossRef]

8. Ohtani, R.; Arai, M.; Hori, A.; Takata, M.; Kitao, S.; Seto, M.; Kitagawa, S.; Ohba, M. Modulation of Spin-Crossover Behavior in an Elongated and Flexible Hofmann-Type Porous Coordination Polymer. J. Inorg. Organomet. Polym. Mater. 2013, 23, 104-110. [CrossRef]

9. Sciortino, N.F.; Zenere, K.A.; Corrigan, M.E.; Halder, G.J.; Chastanet, G.; Létard, J.-F.; Kepert, C.J.; Neville, S.M. Four-step iron(II) spin state cascade driven by antagonistic solid state interactions. Chem. Sci. 2017, 8, 701-707. [CrossRef] [PubMed] 
10. Galet, A.; Muñoz, M.C.; Martinez, V.; Real, J.A. Supramolecular isomerism in spin crossover networks with aurophilic interactions. Chem. Commun. 2004, 2268-2269. [CrossRef] [PubMed]

11. Muñoz, M.C.; Gaspar, A.B.; Galet, A.; Real, J.A. Spin-Crossover Behavior in Cyanide-Bridged Iron(II)-Silver(I) Bimetallic 2D Hofmann-like Metal-Organic Frameworks. Inorg. Chem. 2007, 46, 8182-8192. [CrossRef] [PubMed]

12. Agustí, G.; Muñoz, M.C.; Gaspar, A.B.; Real, J.A. Spin-Crossover Behavior in Cyanide-bridged Iron(II)-Gold(I) Bimetallic 2D Hofmann-like Metal-Organic Frameworks. Inorg. Chem. 2008, 47, 2552-2561. [CrossRef] [PubMed]

13. Kosone, T.; Kachi-Terajima, C.; Kanadani, C.; Saito, T.; Kitazawa, T. A two-step and hysteretic spin-crossover transition in new cyano-bridged hetero-metal $\mathrm{Fe}^{\mathrm{II}} \mathrm{Au}^{\mathrm{I}}$ 2-dimensional assemblage. Chem. Lett. 2008, 37, 422-423. [CrossRef]

14. Kosone, T.; Kachi-Terajima, C.; Kanadani, C.; Saito, T.; Kitazawa, T. Isotope Effect on Spin-crossover Transition in a New Two-dimensional Coordination Polymer $\left[\mathrm{Fe}^{\mathrm{II}}\left(\mathrm{C}_{5} \mathrm{H}_{5} \mathrm{~N}\right)_{2}\right]\left[\mathrm{Au}^{\mathrm{I}}(\mathrm{CN})_{2}\right]_{2},\left[\mathrm{Fe}^{\mathrm{II}}\left(\mathrm{C}_{5} \mathrm{D}_{5} \mathrm{~N}\right)_{2}\right]\left[\mathrm{Au}^{\mathrm{I}}(\mathrm{CN})_{2}\right]_{2}$, and $\left[\mathrm{Fe}^{\mathrm{II}}\left(\mathrm{C}_{5} \mathrm{H}_{5}{ }^{15} \mathrm{~N}\right)_{2}\right]\left[\mathrm{Au}^{\mathrm{I}}(\mathrm{CN})_{2}\right]_{2}$. Chem. Lett. 2008, 37, 754-755. [CrossRef]

15. Kosone, T.; Kanadani, C.; Saito, T.; Kitazawa, T. Synthesis, crystal structures, magnetic properties and fluorescent emissions of two-dimensional bimetallic coordination frameworks $\mathrm{Fe}^{\mathrm{II}}$ (3-fluoropyridine) 2 $\left[\mathrm{Au}^{\mathrm{I}}(\mathrm{CN})_{2}\right]_{2}$ and $\mathrm{Mn}^{\mathrm{II}}$ (3-fluoropyridine $)_{2}\left[\mathrm{Au}^{\mathrm{I}}(\mathrm{CN})_{2}\right]_{2}$. Polyhedron 2009, 28, 1930-1934. [CrossRef]

16. Kosone, T.; Kanadani, C.; Saito, T.; Kitazawa, T. Spin crossover behavior in two-dimensional bimetallic coordination polymer $\mathrm{Fe}^{\mathrm{II}}$ (3-bromo-4-picoline $)_{2}\left[\mathrm{Au}^{\mathrm{I}}(\mathrm{CN})_{2}\right]_{2}$ : Synthesis, crystal structures, and magnetic properties. Polyhedron 2009, 28, 1991-1995. [CrossRef]

17. Kosone, T.; Tomori, I.; Kanadani, C.; Saito, T.; Mochida, T.; Kitazawa, T. Unprecedented three-step spin-crossover transition in new 2-dimensional coordination polymer $\left\{\mathrm{Fe}^{\mathrm{II}}(4 \text {-methylpyridine })_{2}\left[\mathrm{Au}^{\mathrm{I}}(\mathrm{CN})_{2}\right]_{2}\right\}$. Dalton Trans. 2010, 39, 1719-1721. [CrossRef] [PubMed]

18. Rodríguez-Velamazán, J.A.; Carbonera, C.; Castro, M.; Palacios, E.; Kitazawa, T.; Létard, J.-F.; Burriel, R. Two-Step Thermal Spin Transition and LIESST Relaxation of the Polymeric Spin-Crossover Compounds $\mathrm{Fe}(\mathrm{X}-\mathrm{py})_{2}\left[\mathrm{Ag}(\mathrm{CN})_{2}\right]_{2}(\mathrm{X}=\mathrm{H}$, 3-methyl, 4-methyl, 3,4-dimethyl, 3-Cl). Chem. Eur. J. 2010, 16, 8785-8796. [CrossRef] [PubMed]

19. Kosone, T.; Kitazawa, T. Guest-dependent spin transition with long range intermediate state for 2-dimensional Hofmann-like coordination polymer. Inorg. Chim. Acta 2016, 439, 159-163. [CrossRef]

20. Chiruta, D.; Linares, J.; Garcia, Y.; Dimian, M.; Dahoo, P.R. Analysis of multi-step transitions in spin crossover nanochains. Phys. B Condens. Matter 2014, 434, 134-138. [CrossRef]

21. Okabayashi, J.; Ueno, S.; Kawasaki, T.; Kitazawa, T. Ligand 4-X pyridine ( $\mathrm{X}=\mathrm{Cl}, \mathrm{Br}, \mathrm{I})$ dependence in Hofmann-type spin crossover complexes: Fe(4-Xpyridine $)_{2}\left[\mathrm{Au}(\mathrm{CN})_{2}\right]_{2}$. Inorg. Chim. Acta 2016, 445, 17-21. [CrossRef]

22. Krzystek, J.; Ozarowski, A.; Telser, J. Multi-frequency, high-field EPR as a powerful tool to accurately determine zero-field splitting in high-spin transition metal coordination complexes. Coord. Chem. Rev. 2006, 250, 2308-2324. [CrossRef]

23. Nakano, K.; Suemura, N.; Yoneda, K.; Kawata, S.; Kaizaki, S. Substituent effect of the coordinated pyridine in a series of pyrazolato bridged dinuclear diiron(II) complexes on the spin-crossover behavior. Dalton Trans. 2005, 740. [CrossRef] [PubMed]

24. Sheldrick, G.M. SADABS, Program for Empirical Absorption Correction for Area Detector Data; University of Göttingen: Göttingen, Germany, 1996.

25. Sheldrick, G.M. SHELXL, Program for the Solution of Crystal Structures; University of Göttingen: Göttingen, Germany, 1997.

26. Sakaida, S.; Otsubo, K.; Sakata, O.; Song, C.; Fujiwara, A.; Takata, M.; Kitagawa, H. Crystalline coordination framework endowed with dynamic gate-opening behaviour by being downsized to a thin film. Nat. Chem. 2016, 8, 377-383. [CrossRef] [PubMed]

(c) 2017 by the authors. Licensee MDPI, Basel, Switzerland. This article is an open access article distributed under the terms and conditions of the Creative Commons Attribution (CC BY) license (http:/ / creativecommons.org/licenses/by/4.0/). 